\title{
Current Clinical Options for the Management of Itch in Atopic Dermatitis
}

\section{Zoe M Lipman \\ Angelina Labib \\ Gil Yosipovitch}

Dr. Phillip Frost Department of Dermatology and Cutaneous Surgery and Miami Itch Center, University of Miami Miller School of Medicine, Miami, FL, USA
Correspondence: Gil Yosipovitch Dr Phillip Frost Department of Dermatology and Miami Itch Center, University of Miami Hospital, I600 NW IOth Ave RMSB Building, 2067B

$\mathrm{Tel}+$ I 3052I35824

Email gyosipovitch@med.miami.edu
Abstract: Pruritus is the most burdensome and prevalent symptom in patients suffering from atopic dermatitis. Treating atopic itch has historically been a challenge due to multiple underlying mechanisms within its pathogenesis and an incomplete understanding of them. In recent years, our understanding of these mechanisms have increased tremendously and subsequently, new treatments have reached the market that target the pathophysiology of atopic itch from different angles. In addition, there are several promising new treatments currently in development and trials. In the current article, we discuss these currently available treatment options, their available evidence and efficacy, and highlight some of the more recent advancements in the field.

Keywords: eczema, pruritus, itch, atopic dermatitis

\section{Introduction}

Atopic dermatitis (AD) is a common, chronic, inflammatory skin disease with an increasing prevalence in recent decades. ${ }^{1}$ The clinical features of AD include skin dryness, erythema, oozing, crusting, and lichenification, all of which can be extremely bothersome to patients. However, the most common symptom and the symptom with the greatest disease burden in $\mathrm{AD}$ patients is pruritus. ${ }^{2}$

The prevalence of pruritus in $\mathrm{AD}$ is estimated to be anywhere between $80 \%$ and $100 \%{ }^{3}$ In fact, it is so common in that $\mathrm{AD}$ is often referred to as "the itch that rashes." ${ }^{\prime 4}$ Atopic itch has been shown to have significant negative effects on patients' mood, sleep, functioning, and overall quality of life. ${ }^{5,6}$

Treating atopic itch has historically been a challenge due to multiple underlying mechanisms within its pathogenesis and an incomplete understanding of them. These mechanisms include: skin barrier disruption, an inappropriate type 2 immune response, and peripheral and central neurosensitization of skin. ${ }^{7-10}$ In recent years, our understanding of these mechanisms has increased tremendously and subsequently, many new treatments have reached the market that target the pathophysiology of atopic itch from different angles. In the current article, we discuss these currently available treatment options, their available evidence and efficacy, and highlight some of the more recent advancements in the field. PubMed was used to gather the resources for this review during a research period from May 2021 to July 2021.

\section{Non-Pharmacologic Treatments}

Proper skin hydration and elimination of itch-aggravating triggers is imperative for mitigating itch in patients with AD. As dryness, extreme heat/cold, and stress have 
all previously been noted to be triggers of pruritus, frequent skin moisturization, avoidance of extreme temperatures, and stress reduction are useful recommendations to provide patients within a treatment regimen. In addition, there are several specific alterations patients can make to their daily routines that can help eliminate and prevent itch.

\section{Soaps, Cleansers, and Bleach}

Gentle cleansers should be recommended to patients for use during bathing. A good gentle cleanser includes a very minimal number of excess ingredients (eg, fragrance or color), has a low $\mathrm{pH}$ (to help maintain the skin's naturally acidic $\mathrm{pH}$ of 5.5), and is typically "soap free" (made from synthetic detergents instead, which are typically gentler than soaps). In addition, the use of bleach to alleviate pruritus has been employed in individuals with $\mathrm{AD}$. Studies suggest that bleach baths have been shown to decrease the symptoms experienced due to $\mathrm{AD}$; however, bleach baths were not found to be more efficacious than water baths. ${ }^{11}$

\section{Topical Emollients}

Dryness has been noted to be an important trigger of pruritus. ${ }^{12,13}$ As such, topical emollients, like moisturizing creams and lotions, should be used at least once daily. As the skin is better able to absorb moisture while damp, patients should be told to moisturize immediately after showering. ${ }^{14}$ In addition, there are several over the counter moisturizing products that contain antipruritic ingredients (eg, pramoxine, menthol).

One technique that has been found to be successful is the use of "wet-wraps" with topical emollients. To create a wet wrap, or "wet pajama" emollients are applied to the skin and a dampened cotton garment is worn over the affected area; then, a dry garment is worn on top. ${ }^{15}$ In addition to soothing the skin, this technique also disrupts the "itch-scratch cycle" by limiting access to the skin.

\section{Topical CBD Ointments}

There are several topical cannabinoid (CBD) oils that claim to have antipruritic effects for eczema. A large open label trial of $\mathrm{AD}$ patients analyzed the use of a cream containing N- Palmitoylethanolamine, a fatty acid derivative cannabinoid (PEA), and found that it demonstrated an anti-pruritic effect in AD. ${ }^{16,17}$ However, while reviewing the results of this study, it is important to recognize the sample size included 3000 individuals and not all used the topical cream. Additionally, the cream utilized in the study included other products that may affect the direct correlation between PEA and antiitching. Overall, as the market for CBD products in personal skin care has exponentially grown in the last 5 years and continues to grow, more research is required to assess the anti-pruritic effects of these formulations.

\section{Stress Reduction}

Relaxation techniques, such as progressive muscle relaxation, meditation, acupressure and acupuncture have been shown to decrease atopic itch through decreasing stress. ${ }^{18-20}$ Referral to adjunctive psychological counselling may also be beneficial for patients who are expressively or visibly stressed. ${ }^{21}$

\section{Topical Pharmacologic Treatments}

Many cases of localized atopic itch can be successfully treated with topical or intralesional therapeutic agents. The vast majority of these agents act directly on the disease pathogenesis by minimizing local inflammation. The treatments discussed below are also summarized in Table 1.

\section{Capsaicin}

Capsaicin is an active alkaloid compound that is found in chili peppers. ${ }^{22}$ Thought to provide analgesic and antipruritic effects, capsaicin is a cream available over the counter that has been used topically to alleviate symptoms of AD. One clinical trial found that capsaicin reduced itch in individuals with healthy skin significantly when compared to individuals with $\mathrm{AD}$, suggesting the use of capsaicin is more targeted to histamine itch cycles. ${ }^{23}$

\section{Topical Corticosteroids}

Topical corticosteroids have been a mainstay in AD treatment for decades and continue to be effective in decreasing local inflammation caused by AD. While they do not directly treat pruritus, improving the disease as whole was noted to be successful in reducing itch in patients. ${ }^{22}$ Taking into account the disease severity, the most effective yet least potent steroid should be prescribed. In addition, long-term use should be limited to prevent cutaneous atrophy and hypothalamic-pituitary axis suppression. ${ }^{24}$

\section{Topical Calcineurin Inhibitors}

Pimecrolimus and tacrolimus are topical calcineurin inhibitors (TCIs) that are used as steroid-sparing agents for the treatment of $\mathrm{AD}$. While topical steroids are considered first-line agents for the treatment of $\mathrm{AD}$, TCIs are second-line treatments that are particularly used for more gentle areas, such as the face, 
Table I Topical Treatment Options for Atopic Itch

\begin{tabular}{|c|c|c|c|}
\hline Medication & Dose & Useful in: & Notes \\
\hline $\begin{array}{l}\text { Topical } \\
\text { corticosteroids }\end{array}$ & Variable & Patients with visible lesions & $\begin{array}{l}\text { Begin with lower potency doses and only increase } \\
\text { as needed. } \\
\text { Keep potencies low in children, on face, and in skin } \\
\text { folds. } \\
\text { Avoid long term use }\end{array}$ \\
\hline \multirow{2}{*}{$\begin{array}{l}\text { Topical } \\
\text { calcineurin } \\
\text { inhibitors }\end{array}$} & $\begin{array}{l}\text { Tacrolimus } 0.03 \% \text { and } 0.1 \% \\
\text { ointment }\end{array}$ & \multirow[t]{2}{*}{$\begin{array}{l}\text { Inflammatory skin conditions, } \\
\text { particularly facial and anogenital itch }\end{array}$} & \multirow[t]{2}{*}{$\begin{array}{l}\text { May experience transient stinging or burning } \\
\text { sensation }\end{array}$} \\
\hline & Pimecrolimus $1 \%$ cream & & \\
\hline Capsaicin & $\begin{array}{l}0.025 \text { to } 0.1 \% \text { cream } \\
\text { applied up to } 4 \text { times daily }\end{array}$ & Localized itch & $\begin{array}{l}\text { Burning sensation for the first } 2 \text { weeks } \\
\text { Can recommend use of lidocaine prior to } \\
\text { application to minimize application site burning }\end{array}$ \\
\hline $\begin{array}{l}\text { Topical PDE4 } \\
\text { inhibitors }\end{array}$ & Crisaborole $2 \%$ ointment & Mild to moderate atopic dermatitis & Potential burning, stinging, irritation of the skin \\
\hline \multirow[t]{3}{*}{$\begin{array}{l}\text { Local } \\
\text { Anesthetics }\end{array}$} & Pramoxine I to $2.5 \%$ & Face pruritus & $\begin{array}{l}\text { May experience skin irritation and dryness at the } \\
\text { affected area }\end{array}$ \\
\hline & $\begin{array}{c}\text { Ketamine } 5 \text { or } 10 \%+ \\
\text { amitriptyline } 5 \%+\text { lidocaine } 5 \%\end{array}$ & Many forms of chronic itch & $\begin{array}{l}\text { Limit application to the most severely affected } \\
\text { areas }\end{array}$ \\
\hline & $5 \%$ urea $+3 \%$ polidocanol & & Not yet available in the US \\
\hline
\end{tabular}

eyelid, and skin folds as well as prophylactically to minimize flares. ${ }^{25}$ The main mechanism of action of TCIs is inhibition of inflammatory cytokines release by T-cells. ${ }^{26}$ TCIs have also been shown to have anti-pruritic effects theorized to be a result of transient receptor potential cation channel subfamily V member 1 (TRPV1) overstimulation and subsequent desensitization on itch transmitting nerve fibers. ${ }^{27}$ A systemic review of 22 randomized controlled trials including patients with $\mathrm{AD}$ revealed that pruritus was reduced by $36 \%$ with the use of TCIs when compared to placebo. ${ }^{28}$ An additional double-blind placebo-controlled study found that the use of $1 \%$ pimecrolimus significantly provided pruritic relief within 48 hours and with continued use thereafter. $^{29}$

One common side effect is a transient burning sensation on the application site; however, it has been shown that this effect is correlated with improved results likely due to the overstimulation of TRPV1 channels. ${ }^{30}$ In addition, there has been concern over the black box warning for malignancy with the use of high oral doses of TCIs according to a Food and Drug Administration (FDA) approved toxicity study. ${ }^{31}$ There has been no evidence of causality between the use of TCIs and malignancy to date; on the contrary, long-term studies on safety and post-market surveillance has shown that patients exposed to TCIs have lower incidence of malignancy when compared to the general population. ${ }^{32}$

\section{PDE4 Inhibitors (Crisaborole)}

In 2016, the phosphodiesterase-4 (PDE4) inhibitor crisaborole $2 \%$ topical ointment was approved for the treatment of mild to moderate atopic eczema. ${ }^{33}$ PDE4 inhibitors reduce the release of inflammatory cytokines, such as TNF alpha, IL-12, and IL$23 .^{34}$ In a Phase 1 study on patients as young as 2 years old to 17 years old, crisaborole was found to be more effective than the control at reducing both the symptoms of AD and associated itch with a favorable side effect profile; however, continued study of crisaborole is necessary. ${ }^{35}$ Another study reported approximately 60\% improvement in scores measuring pruritus following 5 days of treatment with crisaborole. ${ }^{36}$ Crisaborole was shown to rapidly provide itch relief in mild to moderate $\mathrm{AD}$ in as little as 2 days in analysis of a two-Phase III trial. $^{37,38} \mathrm{~A}$ post hoc analysis demonstrated that the major contribution to improvement of quality of life for $\mathrm{AD}$ patients on crisaborole was its improvement in itch. Skin irritation at the application site is the most common adverse reaction. Overall, the use of PDE4 inhibitors provides an alternative for topical treatment of pruritis in $\mathrm{AD}$. 


\section{Local Anesthetics}

Topical anesthetics target ion channels from the transient receptor channel family on cutaneous skin to numb the application region and can provide relief to patients experiencing pruritis from $\mathrm{AD}$. Creams containing a ketamine, amitriptyline, and lidocaine (KAL) formulation such as those found in base formula Lipoderm can be effective in pruritic management in AD. Sixty-three percent of a total of 93 patients in a retrospective study experiencing chronic itch reported reduced pruritis score ratings with consistent use of KAL topical cream as an add-on treatment, supporting its use in $\mathrm{AD} .{ }^{39}$ Additional local anesthetics, such as polidocanol and topical strontium, have anti-itch properties that can be useful in the treatment of $\mathrm{AD}$ associated pruritis.

\section{Systemic Pharmacologic}

\section{Treatments}

For patients with diffuse $\mathrm{AD}$ and/or generalized itch, topical treatments have limited efficacy. Therefore, in these patients, as well as patients unresponsive to topical therapies, systemic treatments are typically useful. In 2017, the approval of dupilumab, the monoclonal antibody of IL-4 receptor alpha, for the treatment of moderate and severe $\mathrm{AD}$ has dramatically changed the landscape of treatments for $\mathrm{AD}$ and itch and led to a new era of treatment of itch in AD. A summary of the treatments discussed below can be found in Table 2 .

\section{Dupilumab}

Dupilumab is a fully humanized monoclonal antibody that has been shown to have dramatic anti-pruritic effects as early as the first week in patients suffering from $\mathrm{AD}^{40-42}$ It is currently the only FDA approved biologic for the treatment of AD. It acts through competitively binding the shared alpha subunit of the IL-4 receptor which inhibits IL-4 and IL-13 signal transduction. $^{41}$ In two phase III trials, about $40 \%$ of patients taking dupilumab every 14 days reported a decrease in peak pruritus scores of 4 or more from baseline to week $16 .{ }^{53}$ The anti-pruritic effect occurs early in the treatment in as few as 3 days into treatment. ${ }^{43}$ The weekly average of peak pruritus NRS scores in all clinical trials demonstrated significant improvement from baseline in the dupilumab treatment groups versus the control. This improvement was seen at all timepoints and was maintained through the length of the studies (up to 52 weeks). ${ }^{44}$

This drug is also relatively safe, with minor side effects of conjunctivitis and injection site reactions being the most common. ${ }^{45}$ In patients with severe AD and atopic itch, dupilumab should now be the first-line treatment option.

\section{Broad Spectrum Immunosuppressants Systemic Corticosteroids}

While systemic corticosteroids are excellent immunosuppressive drugs that have been shown to successfully improve $\mathrm{AD}$ and atopic itch, their long-term use in $\mathrm{AD}$ patients is contraindicated due to the many associated side effects and high risk of rebound flaring. ${ }^{46}$ Systemic corticosteroids should be used with caution only in the case of flares and for only several (2-3) weeks at a time. ${ }^{22}$

\section{Cyclosporine}

Cyclosporine is a potent immunosuppressant drug that decreases IL-2 production and subsequent T cell activation. ${ }^{47}$ Cyclosporine was previously recommended as a first line systemic treatment for short-term use in moderate-to-severe $\mathrm{AD}$ given its efficacy. ${ }^{25}$ However, its side effects, such as hypertension, elevated creatinine, elevated blood urea nitrogen, opportunistic infection, and broad spectrum immune suppression, have since resulted in a higher drug discontinuation rate and lower efficacy compared to newer targeted systemic agents, like dupilumab. ${ }^{48,49}$ Still, cyclosporine remains a second line option for the treatment of atopic itch in dupilumab failures, as multiple randomized controlled trials have shown a decline in itch severity by over $70 \%{ }^{50-52}$ If used, it should be used for the shortest effective time period to attain rapid control of an acute flare of $\mathrm{AD}$ and associated pruritus. ${ }^{22}$ In addition, clinicians who prescribe cyclosporine should be aware that rebound $\mathrm{AD}$ flares may occur after drug discontinuation; therefore, it should be titrated down prior to discontinuation. $^{22}$

\section{Methotrexate (MTX)}

MTX is a direct inhibitor of purine synthesis that prevents T-cell proliferation. ${ }^{53}$ It has demonstrated antipruritic effects in atopic itch in the elderly and in patients with eczema with lichen amyloidosis. ${ }^{54,55}$ The effective weekly dose of MTX is $12.5-15 \mathrm{mg}$ a week.

It has also shown similar efficacy for $\mathrm{AD}$ itch as azathioprine but with a better safety profile. ${ }^{53}$ 
Table 2 Systemic Treatment Options for Atopic Itch

\begin{tabular}{|c|c|c|c|c|c|}
\hline Drug Category & Drug & Dosing & Useful in: & Avoid in: & Notes: \\
\hline \multirow[t]{2}{*}{ Gabapentinoids } & Gabapentin & $\begin{array}{c}\text { Adults: } \\
100 \text { to } 3600 \mathrm{mg} \text { per day, } \\
\text { usually given in } 2 \text { to } 3 \text { divided } \\
\text { daily doses }\end{array}$ & $\begin{array}{l}\text { Prior to advancing use with } \\
\text { a biologic or } \\
\text { immunosuppressant }\end{array}$ & Children & $\begin{array}{l}\text { Sedation and weight gain are } \\
\text { common adverse effects } \\
\text { Safe to use in pregnancy }\end{array}$ \\
\hline & Pregabalin & $\begin{array}{l}\text { Adults: } \\
150 \text { to } 300 \mathrm{mg} \text { per day }\end{array}$ & & & \\
\hline Antidepressants & Mirtazapine & $\begin{array}{l}\text { Adults and children }>10 \text { years: } \\
7.5 \text { to } 15 \mathrm{mg} \text { at night }\end{array}$ & Nocturnal pruritus & $\begin{array}{c}\text { Children }<10 \text { years } \\
\text { Patients with a personal or } \\
\text { family history of bipolar mood } \\
\text { disorder, patients using } \\
\text { psychotropic medication } \\
\text { treatments }\end{array}$ & $\begin{array}{l}\text { Synergistic anti-itch effect when } \\
\text { used with gabapentinoids } \\
\text { Safe to use in pregnancy }\end{array}$ \\
\hline Opioids & Butorphanol & I to $4 \mathrm{mg}$ intranasally daily & $\begin{array}{l}\text { Nocturnal, intractable } \\
\text { pruritus }\end{array}$ & $\begin{array}{l}\text { Patients taking opioids for pain } \\
\text { relief (partial agonism may } \\
\text { precipitate acute withdrawal } \\
\text { symptoms) } \\
\text { Patients with a prior substance } \\
\text { use disorder (weak } \mu \text { - opioid } \\
\text { receptor agonist activity may } \\
\text { increase addictive potential) } \\
\text { Pregnant and lactating patients }\end{array}$ & $\begin{array}{l}\text { Nausea, vomiting, drowsiness } \\
\text { are adverse effects }\end{array}$ \\
\hline \multirow[t]{5}{*}{$\begin{array}{l}\text { Biologics and } \\
\text { Immunosuppressants }\end{array}$} & Cyclosporine & $\begin{array}{l}3-5 \mathrm{mg} / \mathrm{kg} \text { per day divided into } \\
\qquad 2 \text { doses } \\
\text { Typically given for } 4-8 \text { weeks } \\
\text { until improvement is noted, } \\
\text { then lowered to minimum } \\
\text { effective dose for maintenance }\end{array}$ & $\begin{array}{l}\text { Atopic Dermatitis with } \\
\text { prurigo nodularis } \\
\text { comorbidity } \\
\text { Severe AD cases in older } \\
\text { children/adolescents }\end{array}$ & Infants, young children & Safe to use in pregnancy \\
\hline & Methotrexate & $\begin{array}{c}\text { Adults: } \\
\text { Single weekly dose of } 7.5 \text { to } \\
25 \mathrm{mg} \\
\text { Children: } \\
0.5 \mathrm{mg} / \mathrm{kg} \text { once weekly, with } \\
\text { dose gradually increased as } \\
\text { needed to maximum of } 25 \mathrm{mg} / \\
\text { week } \\
\text { Daily folic acid (I } \mathrm{mg} \text { ) } \\
\text { supplementation for all ages }\end{array}$ & $\begin{array}{l}\text { Atopic dermatitis with } \\
\text { prurigo nodularis } \\
\text { comorbidity } \\
\text { Children with severe AD for } \\
\text { whom cyclosporine is } \\
\text { contraindicated or not } \\
\text { tolerated }\end{array}$ & $\begin{array}{l}\text { Infants, young children } \\
\text { Pregnant patients }\end{array}$ & \\
\hline & Dupilumab & $\begin{array}{l}\text { Adults or children } \geq 60 \mathrm{~kg} \text { : } \\
\text { loading dose: } 600 \mathrm{mg} \\
\text { maintenance dose: } 300 \mathrm{mg} \\
\text { every other week } \\
\text { Children <60kg: loading dose: } \\
400 \mathrm{mg} \\
\text { maintenance dose: } 200 \mathrm{mg} \\
\text { every other week }\end{array}$ & Moderate to severe $A D$ & Children $<6$ years & $\begin{array}{l}\text { Anti-IL-4/- } 13 \text { antibody } \\
\text { Good response in patients with } \\
\text { comorbid atopic conditions (eg } \\
\text { asthma, allergic rhinitis) } \\
\text { Animal studies are promising for } \\
\text { the use in human pregnancy }\end{array}$ \\
\hline & $\begin{array}{c}\text { Mycophenolate } \\
\text { Mofetil }\end{array}$ & $\begin{array}{l}\text { Adults: } \\
\text { 1000-2000mg/day } \\
\text { Children: } \\
20-40 \mathrm{mg} / \mathrm{kg} \text { daily }\end{array}$ & $\begin{array}{l}\text { Second-line treatment } \\
\text { for AD when other } \\
\text { immunosuppressive } \\
\text { treatments are } \\
\text { contraindicated or not } \\
\text { tolerated }\end{array}$ & & $\begin{array}{l}\text { 6-8 weeks elapsed time prior to } \\
\text { clinical treatment response } \\
\text { Studies in children are limited }\end{array}$ \\
\hline & Azathioprine & $\begin{array}{l}\text { Adults: } \\
2 \text { to } 3 \mathrm{mg} / \mathrm{kg} \text { daily } \\
\text { Children: } \\
1-2.5 \mathrm{mg} / \mathrm{kg} \text { daily }\end{array}$ & $\begin{array}{l}\text { Second-line treatment } \\
\text { for AD when other } \\
\text { immunosuppressive } \\
\text { treatments are } \\
\text { contraindicated or not } \\
\text { tolerated }\end{array}$ & & $\begin{array}{l}\text { 4-8 weeks elapsed time prior to } \\
\text { clinical treatment response } \\
\text { Prior to treatment initiation, } \\
\text { thiopurine methyltransferase } \\
\text { (TPMT) levels should be } \\
\text { assessed to determine dose } \\
\text { adjustment } \\
\text { Limited studies in children } \\
\text { Routine monitoring of } \\
\text { hematologic parameters and } \\
\text { LFTs are required }\end{array}$ \\
\hline
\end{tabular}




\section{Mycophenolate Mofetil (MMF)}

MMF inhibits both T-cell and B-cell proliferation and subsequent antibody production by acting as a reversible inhibitor of inosine monophosphate dehydrogenase. Several studies have shown that it is both a safe and effective treatment option for severe $\mathrm{AD}$ and atopic itch. ${ }^{56-58}$ Its effect on $\mathrm{AD}$ and pruritus may not be visible or felt until several months into treatment; therefore, it is recommended that cyclosporine be initiated simultaneously to provide initial relief and tapered down several months into treatment. ${ }^{22}$

\section{Azathioprine}

Azathioprine in a purine analog that limits T-cell and B-cell proliferation through inhibition of purine synthesis. In 2014, a systematic review investigating the efficacies of various immunomodulators in the treatment of severe AD recommended azathioprine be used as a second-line treatment following cyclosporine; however, since then, newer and more effective treatments have been developed. ${ }^{50}$ Furthermore, genetic polymorphisms in African Americans with $\mathrm{AD}$ increase the risk of lymphopenia, systemic azathioprine sensitivity, and the reduced activity of the thiopurine methyltransferase (TPMT) with use of azathioprine, suggesting its use as only a third line treatment in this subset of patients. ${ }^{45}$

\section{Non-Immunomodulating Systemic Therapies for Itch \\ Oral Antihistamines}

The relative safety, widespread availability, and affordability of oral antihistamines, both over the counter and prescribed, have made oral antihistamines a very popular choice for treating atopic itch. ${ }^{59}$ However, in the last 2 decades, literature has determined that the mechanism of itch in $\mathrm{AD}$ is largely nonhistaminergic, indicating that antihistaminergic drugs may not be the most effective treatment option. ${ }^{4}$ In addition, the body of evidence supporting their use in $\mathrm{AD}$ is relatively weak, as no large, randomized, placebo controlled trials have been reported to date. A systematic review of second-generation antihistamines, such as fexofenadine, cetirizine, or loratadine, did not find any evidence that these agents are effective in improving atopic itch. ${ }^{60}$ In a trial including 795 children with $\mathrm{AD}$, daily cetirizine was found to be effective in reducing the Scoring of Atopic Dermatitis (SCORAD) score, when used in conjunction with topical corticosteroids; however, the efficacy of cetirizine alone requires further study. ${ }^{61}$ Additionally, in another study including 400 adult patients with $\mathrm{AD}$, daily fexofenadine did reduce pruritus more than placebo, but this reduction was minimal and likely not clinically significant. ${ }^{62}$ In general, oral antihistamines are not recommended for $\mathrm{AD}$ patients who do not have a component of urticaria. However, the more sedating antihistamines may have some benefit in patients whose sleep is disturbed secondary to nocturnal aggravations of itch. ${ }^{63}$

\section{Mirtazapine}

Mirtazapine is a selective serotonin-norepinephrine reuptake inhibitor that also has antihistaminergic properties. It is specifically well-suited for treating $\mathrm{AD}$ patients with nocturnal pruritic aggravations, as it has been shown to decrease nocturnal pruritus in $\mathrm{AD}$ and many other pruritic diseases due to its sedating nature. ${ }^{64-66}$ While its mechanism of action in reducing itch is unclear, it has been suggested that the perception of pruritus in the brain may be impacted by increased synaptic serotonin and norepinephrine levels. ${ }^{67}$ When used in conjunction with gabapentinoids (see below), a synergistic anti-itch effect is produced and neural sensitization is reduced. Increased appetite and weight gain are the most common side effects of mirtazapine and this drug should not be used in children below the age of 10 .

\section{Gabapentinoids}

While the mechanism of action of gabapentin and pregabalin is still unclear, their role in itch reduction likely involves reducing central neural hypersensitization. ${ }^{68}$ These drugs can be used as monotherapy or in conjunction with mirtazapine, and are good options when the AD disease is not extensive or severe enough to justify the use of a biologic or immunosuppressant. Common side effects include sedation, increased appetite, and weight gain.

\section{Opioids (Kappa Agonist and Mu Antagonists)}

Kappa opioids effective in treating pruritus antagonize the mu-opioid receptor, agonize the kappa-opioid receptor, or do a combination of both, as activation of mu-opioid receptors has been proven to be pro-pruritic and kappaopioid receptors to be anti-pruritic. ${ }^{69-71}$ Specifically, butorphanol, a combination kappa-opioid receptor agonist and mu-opioid receptor antagonist, has been shown to decrease itch intensity. ${ }^{72}$ This drug can be administered intranasally, has a rapid onset of action, and has low abuse potential compared to other opioids. Side effects include drowsiness, which may be useful for the treatment of nocturnal pruritus, as well as constipation and nausea. Additionally, naltrexone is an opioid antagonist that has 
demonstrated efficacy in minimizing pruritis in patients with atopic dermatitis according to a randomized control trial including 38 individuals. $^{73}$

\section{Other}

\section{Phototherapy}

The use of phototherapy for the treatment of AD has been shown to be efficacious in targeting atopic itch. Although the mechanism is unclear, it is thought that phototherapy may reduce pruritus in $\mathrm{AD}$ by reducing sensitivity of sensory nerve fibers that are involved in cutaneous itch. ${ }^{74}$ Additionally, treatment with phototherapy is successful in treating atopic itch by targeting T-cells and attenuating the inflammatory response. ${ }^{75}$ In particular, the narrow UBV wavelength appears to be the most effective form of phototherapy. ${ }^{76}$ When utilized in a study of patients with $\mathrm{AD}$ associated pruritus, $93 \%$ of patients reported decreased severity of itch following treatment with NB-UVB when compared to phototherapy treatment with UVA wavelength, for which $63 \%$ of patients reported decreased severity of itch. Treatment may yield aggravation of itch in the first 2 weeks before improvement of symptoms; therefore, it is important to educate patients on the progression of disease when initiating phototherapy treatment. $^{76}$

\section{Emerging Treatment Options Topicals Tapinarof}

Tapinarof is a naturally-derived molecule that activates aryl hydrocarbon receptor; this inhibits inflammatory mediators, enhances the skin barrier, and reduces itch. ${ }^{77}$ Its efficacy has been found in individuals with both $\mathrm{AD}$ and psoriasis. $^{78}$

\section{PDE-4 Inhibitors}

New PDE-4 inhibitor topicals, such as roflumilast once daily, are undergoing phase III trials in atopic eczema. A meta-analysis concluded that roflumilast is both a safe and effective treatment for mild-to-moderate $\mathrm{AD} .^{79}$ It is thought to have more potent anti-pruritic effects than the existing PDE-4 inhibitors in the market.

\section{JAK-STAT Inhibitors}

The Janus kinase (JAK) signal transducer and activator of transcription (STAT) pathway has been shown to play a role in $\mathrm{AD}$ by dysregulating immune responses, upregulating proinflammatory cytokines, and downregulating antimicrobial peptides that are responsible for skin barrier function. Several drugs that act on this pathway are in development for the treatment of $\mathrm{AD}$ and atopic itch and have been promising thus far. Tofacitinib, a small-molecule JAK inhibitor, has been shown to directly suppress cytokines such as IL-4 and mitigate signal transduction in keratinocytes. ${ }^{80}$ Additionally, there is evidence that tofacitinib may play a role in the downregulation of IL-31, a cytokine which is associated with increased pruritus, through the inhibition of JAK1 and JAK2 ${ }^{81-83}$ Sixty-nine patients with mild to moderate $\mathrm{AD}$ were treated with either $2 \%$ tofacitinib ointment or vehicle ointment in a phase IIa study and pruritus was found to be significantly reduced following a 4 week treatment period. ${ }^{84}$ Pruritic relief was observed as early as day 1 , demonstrating a rapid onset of efficacy. ${ }^{84}$ Additionally, the occurrence of adverse effects was not significant when compared to vehicle ointment and there were no reports of herpes zoster, opportunistic infection, and malignancy. Further studies on the use of topical tofacitinib in patients with $\mathrm{AD}$ is necessary to advance treatment use but there is promising potential to target pruritis in addition to existing topicals.

Selective JAK1 and JAK2 inhibitor, ruxolitinib, has also demonstrated therapeutic efficacy in managing $\mathrm{AD}$ symptoms such as itch. A clinical trial including 307 patients comparing the use of ruxolitinib cream to vehicle cream found statistically significant improvement in Eczema Area and Severity Index, Investigators Global Assessment, and itch numerical rating scales. ${ }^{85}$

Delgocitinib, a pan-JAK inhibitor in topical ointment formulation, was recently approved in Japan and shown to be both effective and well-tolerated in patients with moderate-to-severe $\mathrm{AD}^{86}$

\section{Systemic Therapies}

Abrocitinib, an oral JAK1 inhibitor, displayed equal efficacy as dupilumab in treating $\mathrm{AD}$ unresponsive to topical treatments in a recent Phase III clinical trial. ${ }^{87,88}$ Upadacitinib, a selective JAK1 inhibitor has shown a significant antipruritic effect in phase $\mathrm{II}^{72}$ and recent phase III trial, ${ }^{89}$ as well as baricitinib, a JAK1/2 inhibitor, has also showed promise in recent trials. ${ }^{89,90}$

\section{Monoclonal Antibodies}

While dupilumab is currently the only biologic approved for $\mathrm{AD}$, this is likely to change within the next few years. Tralokinumab and lebrikizumab, monoclonal antibodies targeting IL-13 alone, are currently in phase III clinical trials and seem promising from the available data to 


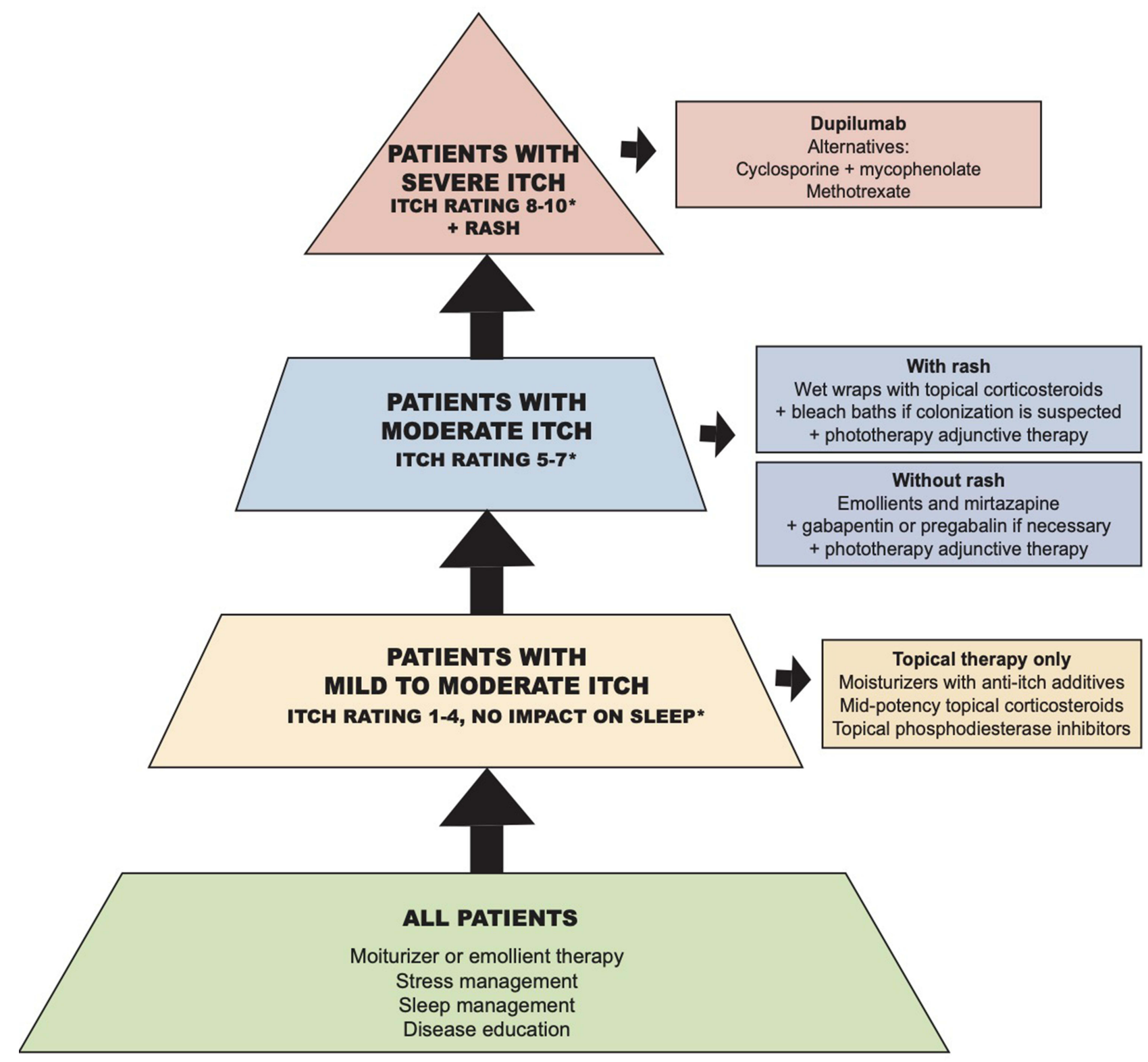

Figure I Therapeutic ladder for the treatment of itch in $A D$.

Notes: *Itch rating based on patient subjective report $0-10$ scale, $0=$ no itch, $10=$ most severe itch.

date. ${ }^{91}$ Anti-IL-31 therapy with nemolizumab targets the itch associated cytokine and has been approved recently for the treatment of AD in European Union and Japan. ${ }^{92}$

\section{P2X3 Agonists}

$\mathrm{P} 2 \mathrm{X} 3$ is an ionotropic receptor that is expressed on the terminals of primary afferent sensory neurons of the dorsal root ganglia (DRG), spinal cord, and brain, mediating pain sensation. ${ }^{93}$ BLU-5937, a P2X3 agonist, is currently under Phase II clinical evaluation for use in AD (NCT04693195, 2021).

\section{Conclusion}

Millions of individuals around the world are afflicted with $\mathrm{AD}$, a complex disease that can produce extremely burdensome itch. While treatment of atopic itch is challenging, advancements in the last several years have provided physicians with multiple options to choose from, ranging from topical agents to systemic therapies, summarized in Figure 1. In addition, newer treatments on the horizon have shown great promise. Overall, improved treatment of atopic itch will improve not only $\mathrm{AD}$ symptoms, but also quality of life in many patients across the globe. 


\section{Disclosure}

Professor Gil Yosipovitch reports grants, personal fees from Pfizer, grants, personal fees from Sanofi Regeneron, grants, personal fees from Galderma, grants, personal fees from LEO, grants, personal fees from Novartis, grants, personal fees from Kiniksa, grants, personal fees from Bellus, personal fees from Eli Lilly, outside the submitted work. The authors declare that they have no other competing interests.

\section{References}

1. Weidinger S, Novak N. Atopic dermatitis. Lancet. 2016;387 (10023):1109-1122. doi:10.1016/S0140-6736(15)00149-X

2. Laughter M, Maymone M, Mashayekhi S, et al. The global burden of atopic dermatitis: lessons from the Global Burden of Disease Study 1990 2017. Br J Dermatol. 2021;184(2):304-309. doi:10.1111/bjd.19580

3. Dawn A, Papoiu A, Chan Y, Rapp S, Rassette N, Yosipovitch G. Itch characteristics in atopic dermatitis: results of a web-based questionnaire. Br J Dermatol. 2009;160(3):642-644. doi:10.1111/ j.1365-2133.2008.08941.x

4. Yosipovitch G, Papoiu AD. What causes itch in atopic dermatitis? Curr Allergy Asthma Rep. 2008;8(4):306-311. doi:10.1007/s11882008-0049-z

5. Zeidler C, Pereira MP, Huet F, Misery L, Steinbrink K, Ständer S. Pruritus in autoimmune and inflammatory dermatoses. Front Immunol. 2019;10:1303. doi:10.3389/fimmu.2019.01303

6. Kamata Y, Tominaga M, Takamori K. Itch in atopic dermatitis management. Itch Manage Clin Pract. 2016;50:86-93.

7. El Hachem M, Di Mauro G, Rotunno R, et al. Pruritus in pediatric patients with atopic dermatitis: a multidisciplinary approach - summary document from an Italian expert group. Ital J Pediatr. 2020;46 (1):11. doi:10.1186/s13052-020-0777-9

8. Elmariah SB. Adjunctive management of itch in atopic dermatitis. Dermatol Clin. 2017;35(3):373-394.

9. Furue M, Yamamura K, Kido-Nakahara M, Nakahara T, Fukui Y. Emerging role of interleukin-31 and interleukin-31 receptor in pruritus in atopic dermatitis. Allergy. 2018;73(1):29-36. doi:10.1111/ all.13239

10. Mollanazar NK, Smith PK, Yosipovitch G. Mediators of chronic pruritus in atopic dermatitis: getting the itch out? Clin Rev Allergy Immunol. 2016;51(3):263-292.

11. Chopra R, Vakharia PP, Sacotte R, Silverberg JI. Efficacy of bleach baths in reducing severity of atopic dermatitis: a systematic review and meta-analysis. Ann Allergy Asthma Immunol. 2017;119 (5):435-440. doi:10.1016/j.anai.2017.08.289

12. Rinaldi G. The itch-scratch cycle: a review of the mechanisms. Dermatol Pract Concept. 2019;9(2):90. doi:10.5826/dpc.0902a03

13. Lodén M. Role of topical emollients and moisturizers in the treatment of dry skin barrier disorders. Am J Clin Dermatol. 2003;4 (11):771-788. doi:10.2165/00128071-200304110-00005

14. Brooks G, Idson B. Skin lipids. Int J Cosmet Sci. 1991;13 (2):103-113. doi:10.1111/j.1467-2494.1991.tb00553.x

15. Krakowski AC, Eichenfield LF, Dohil MA. Management of atopic dermatitis in the pediatric population. Pediatrics. 2008;122 (4):812-824. doi:10.1542/peds.2007-2232

16. Eberlein B, Eicke C, Reinhardt HW, Ring J. Adjuvant treatment of atopic eczema: assessment of an emollient containing N-palmitoylethanolamine (ATOPA study). J Eur Acad Dermatol Venereol. 2008;22(1):73-82.

17. Avila C, Massick S, Kaffenberger BH, Kwatra SG, Bechtel M. Cannabinoids for the treatment of chronic pruritus: a review. $J \mathrm{Am}$ Acad Dermatol. 2020;82(5):1205-1212. doi:10.1016/j. jaad.2020.01.036
18. Bae BG, Ho SO, Park CO, et al. Progressive muscle relaxation therapy for atopic dermatitis: objective assessment of efficacy. Acta Derm Venereol. 2012;92(1):57-61. doi:10.2340/00015555-1189

19. Tan H, Lenon GB, Zhang A, Xue C. Efficacy of acupuncture in the management of atopic dermatitis: a systematic review. Clin Exp Dermatol. 2015;40(7):711-716. doi:10.1111/ced.12732

20. Lee KC, Keyes A, Hensley JR, et al. Effectiveness of acupressure on pruritus and lichenification associated with atopic dermatitis: a pilot trial. Acupunct Med. 2012;30(1):8-11. doi:10.1136/acupmed-2011010088

21. Evers AW, Schut C, Gieler U, Spillekom-van Koulil S, van Beugen S. Itch management: psychotherapeutic approach. In: Szepietowski, J. (Wroclaw) Weisshaar, E. (Heidelberg). editors. Itch-Management in Clinical Practice. Vol. 50. Karger Publishers; 2016:64-70.

22. Pavlis J, Yosipovitch G. Management of itch in atopic dermatitis. Am J Clin Dermatol. 2018;19(3):319-332. doi:10.1007/s40257-0170335-4

23. Weisshaar E, Heyer G, Forster C, Handwerker HO. Effect of topical capsaicin on the cutaneous reactions and itching to histamine in atopic eczema compared to healthy skin. Arch Dermatol Res. 1998;290(6):306-311. doi:10.1007/s004030050309

24. Ference JD, Last AR. Choosing topical corticosteroids. Am Fam Physician. 2009;79(2):135-140.

25. Eichenfield LF, Tom WL, Berger TG, et al. Guidelines of care for the management of atopic dermatitis: section 2. Management and treatment of atopic dermatitis with topical therapies. $J \mathrm{Am}$ Acad Dermatol. 2014;71(1):116-132. doi:10.1016/j. jaad.2014.03.023

26. Tanei R. Atopic dermatitis in older adults: a review of treatment options. Drugs Aging. 2020;37(3):149-160. doi:10.1007/s40266020-00750-5

27. Senba E, Katanosaka K, Yajima H, Mizumura K. The immunosuppressant FK506 activates capsaicin-and bradykinin-sensitive DRG neurons and cutaneous C-fibers. Neurosci Res. 2004;50(3):257-262. doi:10.1016/j.neures.2004.07.005

28. Sher LG, Chang J, Patel IB, Balkrishnan R, Jr A. Relieving the pruritus of atopic dermatitis: a meta-analysis. Acta Derm Venereol. 2012;92(5):455-461. doi:10.2340/00015555-1360

29. Kaufmann R, Bieber T, Helgesen A, et al. Onset of pruritus relief with pimecrolimus cream $1 \%$ in adult patients with atopic dermatitis: a randomized trial. Allergy. 2006;61(3):375-381. doi:10.1111/j.13989995.2005.00977.x

30. Pereira U, Boulais N, Lebonvallet N, Pennec JP, Dorange G, Misery L. Mechanisms of the sensory effects of tacrolimus on the skin. $B r \quad J$ Dermatol. 2010;163(1):70-77. doi:10.1111/j.13652133.2010.09757.x

31. Siegfried EC, Jaworski JC, Hebert AA. Topical calcineurin inhibitors and lymphoma risk: evidence update with implications for daily practice. Am J Clin Dermatol. 2013;14(3):163-178. doi:10.1007/ s40257-013-0020-1

32. Remitz A, Harper J, Rustin M, et al. Long-term safety and efficacy of tacrolimus ointment for the treatment of atopic dermatitis in children. Acta Derm Venereol. 2007;87(1):54-61. doi:10.2340/ 00015555-0167

33. Tom WL, Van Syoc M, Chanda S, Zane LT. Pharmacokinetic profile, safety, and tolerability of crisaborole topical ointment, $2 \%$ in adolescents with atopic dermatitis: an open-label phase $2 \mathrm{a}$ study. Pediatr Dermatol. 2016;33(2):150-159. doi:10.1111/ pde. 12780

34. Nazarian R, Weinberg JM. AN-2728, a PDE4 inhibitor for the potential topical treatment of psoriasis and atopic dermatitis. Curr Opin Investig Drugs. 2009;10(11):1236-1242.

35. Draelos ZD, Murrell D, Hughes M, Zane L. Post hoc analyses of the effect of crisaborole topical ointment, $2 \%$ on atopic dermatitis: associated pruritus from phase 1 and 2 clinical studies. J Drugs Dermatol. 2016;15(2):172-176. 
36. Zane LT, Kircik L, Call R, et al. Crisaborole topical ointment, $2 \%$ in patients ages 2 to 17 years with atopic dermatitis: a phase $1 \mathrm{~b}$, Open-Label, Maximal-Use Systemic Exposure Study. Pediatr Dermatol. 2016;33(4):380-387. doi:10.1111/pde.12872

37. Yosipovitch G, Stein Gold LF, Lebwohl MG, Silverberg JI, Tallman AM, Zane LT. Early relief of pruritus in atopic dermatitis with crisaborole ointment, a non-steroidal, phosphodiesterase 4 inhibitor. Acta Derm Venereol. 2018;98(5-6):484-489. doi:10.2340/ 00015555-2893

38. Simpson EL, Yosipovitch G, Bushmakin AG, et al. Direct and indirect effects of crisaborole ointment on quality of life in patients with atopic dermatitis: a mediation analysis. Acta Derm Venereol. 2019;99 (9-10):756-761. doi:10.2340/00015555-3181

39. Lee HG, Grossman SK, Valdes-Rodriguez R, et al. Topical ketamine-amitriptyline-lidocaine for chronic pruritus: a retrospective study assessing efficacy and tolerability. J Am Acad Dermatol. 2017;76(4):760-761. doi:10.1016/j.jaad.2016.10.030

40. Simpson EL, Bieber T, Guttman-Yassky E, et al. Two Phase 3 trials of dupilumab versus placebo in atopic dermatitis. $N$ Engl $J$ Med. 2016;375(24):2335-2348. doi:10.1056/NEJMoa1610020

41. Han Y, Chen Y, Liu X, et al. Efficacy and safety of dupilumab for the treatment of adult atopic dermatitis: a meta-analysis of randomized clinical trials. J Allergy Clin Immunol. 2017;140(3):888. doi:10.1016/ j.jaci.2017.04.015

42. Blauvelt A, de Bruin-weller M, Gooderham M, et al. Long-term management of moderate-to-severe atopic dermatitis with dupilumab and concomitant topical corticosteroids (LIBERTY AD CHRONOS): a 1-year, randomised, double-blinded, placebo-controlled, phase 3 trial. Lancet. 2017;389(10086):2287-2303. doi:10.1016/S0140-6736(17)31191-1

43. Fourzali K, Golpanian RS, Yosipovitch G. Dupilumab use in atopic dermatitis and beyond in skin diseases. Immunotherapy. 2020;12 (17):1221-1235. doi:10.2217/imt-2020-0175

44. Silverberg JI, Yosipovitch G, Simpson EL, et al. Dupilumab treatment results in early and sustained improvements in itch in adolescents and adults with moderate to severe atopic dermatitis: analysis of the randomized phase 3 studies SOLO 1 and SOLO 2, AD ADOL, and CHRONOS. J Am Acad Dermatol. 2020;82(6):1328-1336. doi:10.1016/j.jaad.2020.02.060

45. Fourzali K, Yosipovitch G. Safety considerations when using drugs to treat pruritus. Expert Opin Drug Saf. 2020;19(4):467-477. doi:10.1080/14740338.2020.1728252

46. Schmitt J, Schäkel K, Fölster-Holst R, et al. Prednisolone vs. ciclosporin for severe adult eczema. An investigator-initiated double-blind placebo-controlled multicentre trial. $\mathrm{Br} J$ Dermatol. 2010;162 (3):661-668. doi:10.1111/j.1365-2133.2009.09561.x

47. Wahlgren C, Scheynius A, Hägermark Ö. Antipruritic effect of oral cyclosporin A in atopic dermatitis. Acta Derm Venereol. 1990;70 (4):323-329.

48. Spekhorst LS, Ariëns LF, van Der Schaft J, et al. Two-year drug survival of dupilumab in a large cohort of difficult-to-treat adult atopic dermatitis patients compared to cyclosporine A and methotrexate: results from the BioDay registry. Allergy. 2020;75(9):2376. doi:10.1111/all.14324

49. Ariens LF, Gadkari A, Van Os-medendorp H, et al. Dupilumab versus cyclosporine for the treatment of moderate-to-severe atopic dermatitis in adults: indirect comparison using the eczema area and severity index. Acta Derm Venereol. 2019;99(9-10):851-857. doi:10.2340/ 00015555-3219

50. Roekevisch E, Spuls PI, Kuester D, Limpens J, Schmitt J. Efficacy and safety of systemic treatments for moderate-to-severe atopic dermatitis: a systematic review. J Allergy Clin Immunol. 2014;133 (2):429-438. doi:10.1016/j.jaci.2013.07.049

51. Pacor M, Di Lorenzo G, Martinelli N, Mansueto P, Rini G, Corrocher R. Comparing tacrolimus ointment and oral cyclosporine in adult patients affected by atopic dermatitis: a randomized study. Clin Exp Allergy. 2004;34(4):639-645. doi:10.1111/j.1365-2222.2004.1907.x
52. Harper J, Ahmed I, Barclay G, et al. Cyclosporin for severe childhood atopic dermatitis: short course versus continuous therapy. Br J Dermatol. 2000;142(1):52-58. doi:10.1046/j.1365-2133.2000.03241.x

53. Schram M, Roekevisch E, Leeflang M, Bos J, Schmitt J, Spuls P. A randomized trial of methotrexate and azathioprine for severe atopic dermatitis. Syst Treat Atopic Dermatitis. 2011;128(2):89.

54. Kursewicz C, Valdes-Rodriguez R, Yosipovitch G. Methotrexate in the treatment of chronic itch in the geriatric population. Acta Derm Venereol. 2020;100(1-2):1-2. doi:10.2340/00015555-3360

55. Stull CM, Tey HL, Yosipovitch G. Methotrexate for the treatment of recalcitrant primary localized cutaneous amyloidosis: a case series. Acta Derm Venereol. 2018;98(9-10):900-901. doi:10.2340/ 00015555-2991

56. Neuber K, Schwartz I, Itschert G, Dieck A. Treatment of atopic eczema with oral mycophenolate mofetil. Br J Dermatol. 2000;143 (2):385-391. doi:10.1046/j.1365-2133.2000.03667.x

57. Jackson JM, Fowler JJF, Callen JP, Lorenz DJ. Mycophenolate mofetil for the treatment of chronic dermatitis: an open-label study of 16 patients. J Drugs Dermatol. 2010;9(4):356-362.

58. Haeck IM, Knol MJ, Ten Berge O, van Velsen SG, de Bruinweller MS, Bruijnzeel-Koomen CA. Enteric-coated mycophenolate sodium versus cyclosporin A as long-term treatment in adult patients with severe atopic dermatitis: a randomized controlled trial. J Am Acad Dermatol. 2011;64(6):1074-1084. doi:10.1016/j. jaad.2010.04.027

59. He A, Feldman SR, Fleischer AB Jr. An assessment of the use of antihistamines in the management of atopic dermatitis. $\mathrm{J} \mathrm{Am} \mathrm{Acad}$ Dermatol. 2018;79(1):92-96. doi:10.1016/j.jaad.2017.12.077

60. Matterne U, Böhmer MM, Weisshaar E, Jupiter A, Carter B, Apfelbacher CJ. Oral H1 antihistamines as "add-on" therapy to topical treatment for eczema. Cochrane Database Syst Rev. 2019;1 (1):Cd012167.

61. Diepgen TL. Long-term treatment with cetirizine of infants with atopic dermatitis: a multi-country, double-blind, randomized, placebo-controlled trial (the ETAC trial) over 18 months. Pediatr Allergy Immunol. 2002;13(4):278-286. doi:10.1034/j.13993038.2002.01047.x

62. Kawashima M, Tango $T$, Noguchi $T$, Inagi $M$, Nakagawa $H$, Harada S. Addition of fexofenadine to a topical corticosteroid reduces the pruritus associated with atopic dermatitis in a 1-week randomized, multicentre, double-blind, placebo-controlled, parallel-group study. $B r \quad J$ Dermatol. 2003;148(6):1212-1221. doi:10.1046/j.1365-2133.2003.05293.x

63. Sidbury R, Davis DM, Cohen DE, et al. Guidelines of care for the management of atopic dermatitis: section 3. Management and treatment with phototherapy and systemic agents. J Am Acad Dermatol. 2014;71(2):327-349. doi:10.1016/j.jaad.2014.03.030

64. Davis MP, Frandsen JL, Walsh D, Andresen S, Taylor S. Mirtazapine for pruritus. J Pain Symptom Manage. 2003;25(3):288-291. doi:10.1016/S0885-3924(02)00645-0

65. Hundley JL, Yosipovitch G. Mirtazapine for reducing nocturnal itch in patients with chronic pruritus: a pilot study. $J$ Am Acad Dermatol. 2004;50(6):889-891. doi:10.1016/j.jaad.2004.01.045

66. Demierre M-F, Taverna J. Mirtazapine and gabapentin for reducing pruritus in cutaneous T-cell lymphoma. J Am Acad Dermatol. 2006;55(3):543-544. doi:10.1016/j.jaad.2006.04.025

67. Ständer S, Weisshaar E, Luger TA. Neurophysiological and neurochemical basis of modern pruritus treatment. Exp Dermatol. 2008;17 (3):161-169. doi:10.1111/j.1600-0625.2007.00664.x

68. Iannetti G, Zambreanu L, Wise RG, et al. From The Cover: pharmacological modulation of pain-related brain activity during normal and central sensitization states in humans. Proc Natl Acad Sci. 2005;102 (50):18195-18200. doi:10.1073/pnas.0506624102

69. Lipman ZM, Yosipovitch G. An evaluation of difelikefalin as a treatment option for moderate-to-severe pruritus in end stage renal disease. Expert Opin Pharmacother. 2021;22(5):549-555. 
70. Phan NQ, Bernhard JD, Luger TA, Ständer S. Antipruritic treatment with systemic $\mu$-opioid receptor antagonists: a review. J Am Acad Dermatol. 2010;63(4):680-688.

71. Phan N, Lotts T, Antal A, Bernhard J, Ständer S. Systemic kappa opioid receptor agonists in the treatment of chronic pruritus: a literature review. Acta Derm Venereol. 2012;92:555-560. doi:10.2340/00015555-1353

72. Yosipovitch G, Rosen JD, Hashimoto T. Itch: from mechanism to (novel) therapeutic approaches. J Allergy Clin Immunol. 2018;142 (5):1375-1390. doi:10.1016/j.jaci.2018.09.005

73. Malekzad F, Arbabi M, Mohtasham N, et al. Efficacy of oral naltrexone on pruritus in atopic eczema: a double-blind, placebo-controlled study. $J$ Eur Acad Dermatol Venereol. 2009;23(8):948-950. doi:10.1111/j.1468-3083.2009.03129.x

74. Wallengren J, Sundler F. Phototherapy reduces the number of epidermal and CGRP-positive dermal nerve fibres. Acta Derm Venereol. 2004;84(2):111-115. doi:10.1080/00015550310022899

75. Rivard J, Lim HW. Ultraviolet phototherapy for pruritus. Dermatol Ther. 2005;18(4):344-354. doi:10.1111/j.1529-8019.2005.00032.x

76. Reynolds NJ, Franklin V, Gray JC, Diffey BL, Farr PM. Narrow-band ultraviolet $\mathrm{B}$ and broad-band ultraviolet $\mathrm{A}$ phototherapy in adult atopic eczema: a randomised controlled trial. Lancet. 2001;357 (9273):2012-2016. doi:10.1016/S0140-6736(00)05114-X

77. Furue M, Nakahara T. Revival of AHR agonist for the treatment of atopic dermatitis: tapinarof. Curr Treat Options Allergy. 2020;7 (3):414-421. doi:10.1007/s40521-020-00259-7

78. Bissonnette R, Gold LS, Rubenstein DS, Tallman AM, Armstrong A Tapinarof in the treatment of psoriasis: a review of the unique mechanism of action of a novel therapeutic AhR modulating agent (TAMA). J Am Acad Dermatol. 2021;84:1059-1067.

79. Yang H, Wang J, Zhang X, et al. Application of topical phosphodiesterase 4 inhibitors in mild to moderate atopic dermatitis: a systematic review and meta-analysis. JAMA Dermatol. 2019;155(5):585-593. doi:10.1001/jamadermatol.2019.0008

80. Krueger J, Suarez-Farinas M, Fuentes-Duculan J, et al. Pathological immune pathways in psoriasis are rapidly attenuated by tofacitinib treatment: FC32. Br J Dermatol. 2014;171(6):e120-e121.

81. Cornelissen C, Lüscher-Firzlaff J, Baron JM, Lüscher B. Signaling by IL-31 and functional consequences. Eur J Cell Biol. 2012;91(67):552-566. doi:10.1016/j.ejcb.2011.07.006

82. Sonkoly E, Muller A, Lauerma AI, et al. IL-31: a new link between $\mathrm{T}$ cells and pruritus in atopic skin inflammation. J Allergy Clin Immunol. 2006;117(2):411-417. doi:10.1016/j.jaci.2005.10.033

83. Fukuyama T, Ehling S, Cook E, Bäumer W. Topically administered Janus-kinase inhibitors tofacitinib and oclacitinib display impressive antipruritic and anti-inflammatory responses in a model of allergic dermatitis. $J$ Pharmacol Exp Ther. 2015;354(3):394-405. doi:10.1124/jpet.115.223784
84. Bissonnette R, Papp K, Poulin Y, et al. Topical tofacitinib for atopic dermatitis: a phase II a randomized trial. Br J Dermatol. 2016;175 (5):902-911. doi:10.1111/bjd.14871

85. Kim BS, Howell MD, Sun K, et al. Treatment of atopic dermatitis with ruxolitinib cream (JAK1/JAK2 inhibitor) or triamcinolone cream. J Allergy Clin Immunol. 2020;145(2):572-582. doi:10.1016/ j.jaci.2019.08.042

86. Nakagawa H, Nemoto O, Igarashi A, Saeki H, Kaino H, Nagata T. Delgocitinib ointment, a topical Janus kinase inhibitor, in adult patients with moderate to severe atopic dermatitis: a phase 3, randomized, double-blind, vehicle-controlled study and an open-label, long-term extension study. $J$ Am Acad Dermatol. 2020;82 (4):823-831. doi:10.1016/j.jaad.2019.12.015

87. Silverberg JI, Simpson EL, Thyssen JP, et al. Efficacy and safety of abrocitinib in patients with moderate-to-severe atopic dermatitis: a randomized clinical trial. JAMA Dermatol. 2020;156(8):863-873. doi:10.1001/jamadermatol.2020.1406

88. Simpson EL, Sinclair R, Forman S, et al. Efficacy and safety of abrocitinib in adults and adolescents with moderate-to-severe atopic dermatitis (JADE MONO-1): a multicentre, double-blind, randomised, placebo-controlled, phase 3 trial. Lancet. 2020;396 (10246):255-266. doi:10.1016/S0140-6736(20)30732-7

89. Guttman-Yassky E, Thaçi D, Pangan AL, et al. Upadacitinib in adults with moderate to severe atopic dermatitis: 16-week results from a randomized, placebo-controlled trial. J Allergy Clin Immunol. 2020;145(3):877-884. doi:10.1016/j.jaci.2019.11.025

90. Simpson E, Lacour J-P, Spelman L, et al. Baricitinib in patients with moderate-to-severe atopic dermatitis and inadequate response to topical corticosteroids: results from two randomized monotherapy Phase III trials. $B r \quad J$ Dermatol. 2020;183(2):242-255. doi:10.1111/ bjd. 18898

91. Wollenberg A, Howell MD, Guttman-Yassky E, et al. Treatment of atopic dermatitis with tralokinumab, an anti-IL-13 mAb. J Allergy Clin Immunol. 2019;143(1):135-141. doi:10.1016/j.jaci.2018.05.029

92. Kabashima K, Matsumura T, Komazaki H, Kawashima M. Trial of nemolizumab and topical agents for atopic dermatitis with pruritus. N Engl J Med. 2020;383(2):141-150. doi:10.1056/NEJMoa1917006

93. Spinaci A, Buccioni M, Dal Ben D, Marucci G, Volpini R Lambertucci C. P2X3 receptor ligands: structural features and potential therapeutic applications. Front Pharmacol. 2021;12:653561. doi:10.3389/fphar.2021.653561
Clinical, Cosmetic and Investigational Dermatology

\section{Publish your work in this journal}

Clinical, Cosmetic and Investigational Dermatology is an international, peer-reviewed, open access, online journal that focuses on the latest clinical and experimental research in all aspects of skin disease and cosmetic interventions. This journal is indexed on CAS.
Dovepress

The manuscript management system is completely online and includes a very quick and fair peer-review system, which is all easy to use. Visit http://www.dovepress.com/testimonials.php to read real quotes from published authors. 